Pöntör Jenő

\title{
Idealista tendenciák a kortárs elmefilozófiában ${ }^{1}$
}

Az „elme filozófiai problémája” kifejezés hallatán először talán a következő két - egymástól természetesen nem független - kérdés jut eszünkbe: az első, hogy mi a viszony az elme és a fizikai test (agy, idegrendszer) között? Erre a kérdésre próbálnak válaszolni az utóbbi évtizedekben az elmefilozófia berkein belül megfogalmazódott különböző, nagyobb részt fizikalista, kisebb részt dualista elméletek. ${ }^{2}$ A második inkább egy általános metafizikai probléma: milyen helyet foglal el az elme/tudat általában a világ struktúrájában? Ez utóbbi kérdésre kínálnak választ például az idealizmus különböző változatai.

E tanulmányban először áttekintem az idealizmus fogalmát általában, majd részletesebben bemutatom az idealizmus egy olyan, ma kurrens formáját, a pánpszichizmust, ${ }^{3}$ amely mai reneszánszát főleg annak a ténynek köszönheti, hogy (sokak szerint) az imént említett fizikalista és dualista elméletek egyike sem tudott (és talán nem is fog tudni) választ adni az első kérdésre.

\section{Mi az idealizmus? ? $^{4}$}

Mindenekelőtt a következő megállapítással kell kezdenünk: azt, hogy milyen kritériumok teljesülése alapján nevezünk egy filozófiai álláspontot „idealizmusnak”, még nagy vonalakban sem könnyü meghatározni. Ennek az az oka, hogy az „idealizmus” terminusnak a filozófiai nyelven belül is több, egymástól igencsak különböző jelentése létezik.

1 Köszönettel tartozom Kodaj Dánielnek és Paár Tamásnak a cikk korábbi változatához füzött értékes megjegyzéseikért.

2 Lásd ehhez Tözsér 2008.

3 Bár a pánpszichizmus nem minden formája nevezhető a szó igazi értelmében „idealizmusnak”, egyik változata sem tekinthető - úgy gondolom - attól túlzottan távol álló álláspontnak. Nem véletlen, hogy a pánpszichista elméletekre gyakran mint „idealisztikus” elképzelésekre szokás utalni. Ezért látom én is indokoltnak együtt tárgyalni e két elméletcsaládot. A pánpszichizmus és az idealizmus viszonyáról részletesebben lásd Chalmers 2019.

4 A kortárs analitikus idealizmust (illetve pánpszichizmust) átfogóan tárgyaló magyar nyelvủ munkáról nem tudok. Huoranszki 2001 foglalkozik néhány, az idealizmus témájába vágó kérdéssel. Az alábbiakban tárgyalt témák tanulmányozásához - szerintem - a leginkább javasolható angol nyelvű kiindulópontok: Skrbina 2007; Guyer - Horstmann 2015; Brüntrup - Jaskolla 2016; Goff - Seager - Allen Hermanson 2017; Goldschmidt - Pearce 2017. Néhány nagy hatású, valamilyen idealista álláspont mellett érvelő munka (a teljesség igénye nélkül): Foster 1982, 2008; Sprigge 1983; Robinson 2016. 
Így az én - meglehetősen laza - meghatározásom is óhatatlanul önkényes lesz, annak ellenére, hogy igyekszem figyelembe venni a kifejezés tényleges használatát.

Ahhoz, hogy megragadjuk az idealizmus fogalmát, a legcélravezetőbb a tipikus fizikalista világkép egy (erősen leegyszerüsített) megfogalmazásából kiindulnunk. Eszerint egy rétegzett világban élünk, melynek legalsó szintjét az alapvető mikrofizikai entitások - bármik is legyenek azok - képezik. E szint entitásaira épülnek rá a következő szint, a makrofizikai/kémiai szint entitásai, ezekre - egy szinttel feljebb - a biológiai entitások, a mentális entitások pedig a komplexitás magasabb fokát elérő biológiai szerveződésre ráépülő létezők. Végül a legfelső szinten bizonyos organizmusokból álló különböző társadalmi szerveződések helyezkednek el. Ami számunkra most a lényeg, hogy e világkép szerint az elme/tudat csak a legfelsőbb régiókban jelenik meg: a mentális jelenségek csak ritka, esetleges felvillanások a nagyrészt és alapvetően nem mentális fizikai világban, melyek létezése ontológiailag nem mentális entitások komplex konfigurációinak létezésétől függ. ${ }^{6}$

Ahogy látom, az idealizmusnak nevezhető álláspontok leginkább szembetűnő közös vonása, hogy abban a tekintetben mindegyikük radikálisan szemben áll e világképpel, hogy a mentális régiót „lecsúsztatja” a legalsó szintre. Amiben az idealizmus minden formája egyetért: az elme/tudat/szellem ${ }^{7}$ alapvető szerepet játszik a valóság struktúrájában. Némileg pontosabban: idealista metafizikák azok az elképzelések, melyek szerint világunkban az alapvető entitás(ok), amely(ek) létezésétől minden más entitás létezése valamilyen értelemben függ, mentális természetűek. E megállapítás természetesen nagyon messze van attól, hogy egzakt definíció legyen. Ugyanakkor egyrészt ez talán nem is kell, hogy túl nagy problémát jelentsen, minthogy az „idealizmus” sem jól körülhatárolt fogalom, másrészt - ahogy ez majd reményeim szerint látható lesz - arra alkalmas, hogy erre építve érdemleges megállapításokat tegyek az idealizmusról.

A továbbiakban először három olyan elvileg lehetséges elmélettípus logikai „csontvázát" és egymáshoz való viszonyát fogom röviden áttekinteni, melyek valamelyikébe - de nem feltétlenül csak az egyikébe - a most vázolt értelemben „idealistának” nevezhető elképzelések döntő többsége besorolható. Ezek: a klasszikus teizmus, az idealista

5 A „ráépülés” („szuperveniencia”) relációról (és azzal kapcsolatos problémákról) bővebben lásd Tőzsér 2008.

6 Fontos hangsúlyoznunk, hogy ez a tipikusnak tekinthető fizikalista világkép vázlata, ahogy látni fogjuk, a fizikalizmusnak vannak egyéb lehetséges változatai is.

7 Az „elme”, „tudat”, „szellem” terminusokat itt most nagyjából szinonimnak és egyszerűen a „valamilyen mentális entitás” szinonimáinak tekintem. A „mentális” definícióját illető viták tárgyalására e helyütt nem tudok kitérni, de azt hiszem, nem túl merész feltételezés, hogy a legtöbbünk (beleértve az idealisták többségét is) intuíciójának megfelelő közelítő definíció: mentális az, ami intencionális és/vagy fenomenálisan tudatos. (E két fogalom kissé részletesebb tárgyalására később még visszatérek.) 
tulajdonságmonizmus, illetve az antirealizmus. ${ }^{8} \mathrm{~A}$ második részben pedig részletesebben áttekintem a kortárs pánpszichizmust, ami tekinthető az idealista tulajdonságmonizmus egy „puha” formájának.

Első lépésben érdemes megvizsgálni az idealizmus fogalmához szorosan kötődő három másik fogalmat.

\subsection{Monizmus, materializmus, realizmus}

A monizmus fogalma úgy kapcsolódik az idealizmushoz, hogy az idealista metafizikákat monista metafizikáknak szokás tartani. A materializmus, illetve a realizmus pedig úgy, hogy mindkettővel találkozhatunk az idealizmus par excellence tagadásának tekintett elképzelésekre utaló címkékként. Azonban - ahogy látni fogjuk - az idealizmus és az e fogalmakkal jelölt álláspontok viszonya ennél némileg bonyolultabb.

A monista metafizikák valaminek a kizárólagos létét állítják. A monizmus két fó fajtája a szubsztanciamonizmus (vagy kvantitatív monizmus) és a tulajdonságmonizmus (vagy kvalitatív monizmus). A szubsztanciamonizmus általános metafizikai kontextusban (tehát nem a test-elme probléma kontextusában) az a tézis, hogy csak egy szubsztancia (durván: önállóan létezni képes partikuláris dolog) létezik. A szubsztanciamonista szerint az érzéki tapasztalatunk nyújtotta kép, mely szerint a világ egymástól elkülönült dolgokból áll, illúzió: az egymástól különállónak tűnő fizikai tárgyak, események valójában ugyanannak a valóságot alkotó egyetlen szubsztanciának a különböző módosulásai (tulajdonságai, megnyilvánulásai), ahogyan például egy kötélen a csomók ugyanannak a dolognak - a kötélnek - a különböző módosulásai. (Ebből nem következik, hogy a szubsztanciamonizmus mindenképpen inkonzisztens a fizikai tárgyakat illető realizmussal. Egy logikailag lehetséges álláspont - legalábbis ha nem tartjuk a „fizikai tárgy" fogalom esszenciális elemének, hogy a fizikai tárgy a világ többi részétől különálló létező -, hogy a fizikai tárgyak azonosak az egyetlen szubsztancia módosulásaival.)

A szubsztanciamonista tézisből - első pillantásra legalábbis - nem következik, hogy valamilyen elme valamilyen tekintetben alapvető szerepet játszik a valóság felépítésében, így a szubsztanciamonizmust önmagában nem kell idealizmusnak tekintenünk. ${ }^{9}$ Minden olyan metafizika, amely szerint több szubsztancia létezik, természetesen tagadása a szubsztanciamonizmusnak. A tulajdonságmonizmus fó állítása, hogy minden létező - attól függetlenül, hogy hány szubsztancia létezik - egy alapvető típusba sorol-

8 Természetesen az idealista álláspontoknak ettől eltérő „logikai térképei” is felrajzolhatók, például Chalmers 2019.

9 E megállapítást látszik alátámasztani az a tény is, hogy Spinoza - akit alighanem a legtöbben tekintenek a szubsztanciamonizmus első számú képviselojének - idealista értelmezése kisebbségi álláspontnak tekinthető. Persze azért akadnak képviselői: Newlands 2011a, Newlands 2011b. 
ható. Annak alapján, hogy mi ez az alapvető típus, a tulajdonságmonizmus három fő fajtáját különböztethetjük meg: az idealista tulajdonságmonizmust, ${ }^{10}$ a fizikalizmust és a neutrális monizmust. Az idealista változat szerint minden létező mentális természetű (erre persze még visszatérünk). A fizikalizmus szerint minden fizikai természetű. A neutrális monizmus szerint pedig a világ alapvető építőelemei - bármik is legyenek - sem nem mentális, sem nem fizikai, hanem egy harmadik típusba sorolható entitások, és mind a mentális, mind a fizikai régió valamilyen módon ezen alapvetőbb entitástípusba tartozó entitásokra vezethető vissza. ${ }^{11}$

A „materializmus” és a „fizikalizmus” terminusokat ma a legtöbben szinonimákként használják - a továbbiakban én is így fogok tenni -, ami nem meglepő, tekintve, hogy a mai fizikalizmus lényegében a klasszikus materializmus modern formája. Míg a klaszszikus materializmus szerint minden létező anyagi természetü (tömör, kiterjedt, meghatározott alakkal és térbeli pozícióval rendelkező entitás és/vagy ilyen „darabkák” aggregátuma), addig a kortárs fizikalizmus/materializmus szerint minden létező fizikai természetű. Bár megoszlanak a vélemények azt illetően, hogy mit kell e kontextusban "fizikain” érteni, ${ }^{12}$ azt hiszem, nem tévedünk nagyot, ha azt mondjuk, hogy ma a legtöbben a fizikaiság elméletalapú koncepciójának egy változatát fogadják el, amelyet például a következőképp is megfogalmazhatunk: egy entitás akkor és csak akkor fizikai entitás, ha vagy része egy jövőbeli teljes fizikai elmélet ontológiájának, vagy ilyen entitásokra épül rá. (E megfogalmazáson persze még bőven volna mit finomítani, de számunkra most ebben a formában is megfelel.)

E definíciót alapul véve a fizikalizmusnak két - a mi szempontunkból most lényeges - változatát különböztethetjük meg. A példányfizikalizmus (token physicalism) szerint (az aktuális világban) minden partikuláré fizikai partikuláré, ami egészen pontosan azt jelenti, hogy minden partikuláré instanciál legalább egy olyan tulajdonságot, mely vagy azonos egy olyan tulajdonsággal, melyre a teljes fizikai elmélet hivatkozni fog a világ leírásakor, vagy ilyen tulajdonságokra épül rá. E tézis nem zárja ki, hogy fizikai tulajdonságot instanciáló partikuláréknak a fizikai tulajdonságaik mellett legyenek más, nem fizikai tulajdonságaik is. A típusfizikalizmus (type physicalism) szerint (az aktuális világban) minden tulajdonság fizikai tulajdonság, azaz vagy olyan tulajdonság, melyre a teljes fizikai elmélet hivatkozni fog a világ leírásakor, vagy ilyen tulajdonságokra épül rá. (A típusfizikalizmus implikálja a példányfizikalizmust - hacsak a típusfizikalista nem fogadja el minden tulajdonság nélküli „csupasz” partikulárék létezését.)

A materializmus/fizikalizmus mint tulajdonságmonizmus akkor és csak akkor tagadása egy metafizikai elméletnek, ha az vagy nem tulajdonságmonista, azaz tagadja álta-

10 Ezt szokás egyszerüen ,idealizmusnak” is nevezni, de - amint mindjárt ki fog derülni - az idealizmus ennél tágabb fogalom.

11 Lásd például: Mach 1886, Russell 1921, James 1981, Banks 2010.

12 E kérdésről bővebben: Márton 2019. 
lában azt az állítást, hogy van egy olyan alapvető típusa a létezőknek, amelybe minden (az aktuális világban) létező entitás besorolható - ilyen például a karteziánus dualizmus -, vagy tulajdonságmonista ugyan, de azt tagadja, hogy a „fizikai” minden létezőre érvényes kategória lenne. ${ }^{13}$

A metafizikában a „realizmus” terminusnak két jól megragadható jelentését különíthetjük el. Az első: „realizmusnak” nevezhető minden valamely entitástípussal kapcsolatban az adott entitástípus létezését állító álláspont (mint például univerzálékkal kapcsolatos realizmus, modális realizmus stb.). Az ebben az értelemben vett realizmusnak nincsenek fokozatai. Univerzálék, konkrét lehetséges világok vagy léteznek, vagy nem léteznek. A „realizmus” kifejezés második jelentésében - amely számunkra most érdekes - nem valamely speciális entitástípusra, hanem az egész világra vonatkozó álláspontra utal. Az ebben az értelemben vett realista álláspontot a legegyszerűbben talán úgy fogalmazhatjuk meg, hogy az emberi megismerés - azaz a tapasztalat és a gondolkodás tárgyát képező világ létezne akkor is, és nagyjából hasonló lenne az általunk ismert világhoz, ha a világot tapasztaló és kategorizáló emberi elme nem létezne. Másként: a realista szerint a (legtöbbünk által) elmefüggetlennek gondolt (fizikai) világ valóban nem függ ontológiailag az emberi elmétől.

Ha úgy fogalmazunk, hogy az elme nélküli világ „nagyjából hasonló” lenne az ismert világunkhoz (és nemigen fogalmazhatunk másképp, erre az álláspontra nem adhatunk pontosabb definíciót), akkor nyilvánvaló, hogy ez a fajta realizmus különböző mértékű lehet. Így természetesen az ezt tagadó antirealizmus különböző változatainak (amelyekkel leggyakrabban a „kantianizmus”, „idealizmus”, „szubjektivizmus”, „relativizmus”, illetve az egyszerűen minden jelző nélküli „antirealizmus” címkék alatt talál-

13 A „materializmussal” és a ,fizikalizmussal” rokon fogalom még a „naturalizmus” fogalma. Első közelítésben a metafizikai értelemben vett „naturalizmust” úgy definiálhatjuk, hogy az a tézis, mely szerint nem léteznek természetfeletti entitások. (Ekkor a következő lépésben természetesen azt kell tisztáznunk, hogy mit is értünk „természeti”, illetve „természetfeletti entitáson”. Kézenfekvo megoldásnak tűnik, hogy a fizikaiság elméletalapú definíciójának mintájára a „természeti entitást” úgy határozzuk meg, hogy egy entitás akkor és csak akkor természeti, ha vagy része valamely jövőbeli teljes természettudományos elmélet ontológiájának, vagy ilyen entitásokra épül rá. Persze e definíción is bőven volna még mit finomítani.) Akár logikai következménye a fizikalizmusnak a naturalizmus, akár nem, nyilvánvaló, hogy nehezen találnánk olyan fizikalistát, aki nem vallaná magát ebben az értelemben naturalistának. Az viszont egyáltalán nem nyilvánvaló, hogy a naturalizmus implikálja a fizikalizmust: abból, hogy nem léteznek természetfeletti entitások, nem látszik következni, hogy csak fizikai entitások léteznek (persze itt minden attól függ, hogy pontosan hogyan definiáljuk a „fizikai”, illetve a „természetfeletti” terminusokat). Mindenesetre például Chalmers fizikalizmust tagadó „naturalista dualizmusa” (Chalmers 1996) nem tünik inkonzisztens fogalomnak. A metafizikai értelemben vett naturalizmus mellett beszélhetünk a terminusnak egy inkább episztemológiai jelentéséről is. Az „episztemológiai naturalizmus” címkével illethető elképzelések a megismerés bizonyos területein (vagy minden területén) a természettudomány eredményeinek jelentőségét hangsúlyozzák, illetve a tudományos módszer elsőbbségét (vagy egyedüli létjogosultságát) hirdetik. Például: Quine 1999. 
kozhatunk) szintén különböző fokozatai lehetnek. Az így értett antirealizmus annál erősebb, minél nagyobb részben tekinti megismerésünk tárgyát a mi saját konstrukciónknak.

Továbbá az is nyilvánvaló, hogy lehetetlen pontosan meghúzni a határvonalat az ebben az értelemben vett realizmus és antirealizmus között. Hogy mennyire kell gyengének lennie a realizmusnak ahhoz, hogy már antirealizmusról beszélhessünk, függ a kontextustól, és bizonyos mértékig egyéni megítélés kérdése is. Például az elsődleges és a másodlagos tulajdonságokat megkülönböztető észleléselméleteket (melyek szerint léteznek elmefüggetlen fizikai tárgyak, azonban e tárgyak másodlagos tulajdonságai mint például a szín, íz stb. - az észlelő elme nélkül abban a formában, ahogyan számunkra a tapasztalatban adódnak, nem léteznének) még realistának szokás tartani. Azt a kanti elképzelést viszont, mely szerint a tér és az idő (így a tárgyak elsődleges tulajdonságai - mint például az alak, mozgás stb. - is) a mi konstrukcióink, ${ }^{14}$ már antirealistának mondják. Ugyanakkor azt is mondhatjuk, hogy Kant szerint azért mégiscsak van valami elmefüggetlen magánvaló dolog, tehát Kant bizonyos mértékig realista - legalábbis Berkeley-hoz képest, aki szerint az általunk rendesen elmefüggetlennek gondolt világ teljes mértékben saját ideáink halmaza. De akár tovább is folytathatjuk: Berkeley szerint ugyan az észlelt világ azonos a saját ideáink összességével, ennek ellenére nem a mi konstrukciónk. Ugyanis amikor veridikusan észlelünk - a sajátos berkeley-ánus értelemben -, akkor az észlelt ideáink létezésének oka nem mi vagyunk, hanem az emberi elmétől függetlenül létező Isten, tehát Berkeley bizonyos mértékig realista - mondjuk az ateista McTaggarthoz képest.

\subsection{Az idealizmus fó formái}

\subsubsection{Idealizmus I: klasszikus teizmus}

A teizmus meglehetősen tág és egyáltalán nem pontosan definiált fogalom. Én „klasszikus teizmus" alatt mindenesetre azt a tézist értem, hogy létezik egy, a nagy monoteista vallásokhoz kötődő filozófiai istenfogalomnak megfelelő Isten. Ennek az istenfogalomnak a mi szempontunkból most lényeges elemei: Isten valamilyen értelemben személy, tehát mindenképpen szellemi természetű, továbbá a világ teremtője és létben tartója. A világ létezése függ Istentől, de Isten létezése nem függ a világ létezésétől.

Bár a klasszikus teizmust ritkábban szokták „idealizmusnak” nevezni, mint a továbbiakban tárgyalt elképzeléseket, világos, hogy a fentebb mondottak alapján miért te-

14 Legalábbis a tradicionális értelmezés szerin durván ez Kant álláspontja. Vannak azonban ettől eltérő

Kant-interpretációk is, például Langton 1998. 
kinthető idealizmusnak: a klasszikus teizmus szerint minden létező ontológiailag egy szellemi/mentális természetű entitástól függ, amely/aki - mivel nem függ semmitől - a valóság legalapvetőbb szintjét jelenti. Az idealizmus e formája nem kötődik a monizmushoz. Határozottan nem szubsztanciamonista, Isten teremtményei bármennyire szorosan függenek is teremtőjüktől, attól különböző entitások. Továbbá nyilvánvalóan nem implikálja a tulajdonságmonizmust sem: csak annyit állít, hogy minden létező akár besorolható egy alapvető típusba, akár nem - ontológiailag függ Istentől (valójában a legtöbb klasszikus teista metafizika valamilyen formában dualista). Ugyanakkor nem is inkonzisztens a tulajdonságmonizmussal. Az idealista monizmussal - úgy tűnik biztosan nem, ezzel kapcsolatban elég Berkeley idealista teizmusára utalnunk. Továbbá, bár a fizikalisták döntő többsége természetesen nem teista, az sem triviális, hogy a fizikalizmus eo ipso a teizmus tagadásának tekintendő. Logikailag nem kizárható, hogy a fizikaiságnak lehetséges olyan definíciója, amelybe Isten valahogy belefér, így pedig az sem zárható ki, hogy a klasszikus teizmus konzisztensen tartható azzal az állítással, hogy minden entitás fizikai természetű. Például - a fizikaiság elméletalapú koncepcióját alapul véve - logikailag lehetséges, hogy egy fizikai elmélet valamilyen olyan entitást tartalmazzon, ami nagyon hasonlít ahhoz, ,akit mindenki Istennek nevez”. ${ }^{15}$

A klasszikus teista metafizikáknak a realizmus önmagában nyilvánvalóan nem tagadása, sőt inkább természetes módon kapcsolódik azokhoz - elvégre e metafizikák szerint Isten és nem az emberi elme teremti a világot. ${ }^{16}$

\subsubsection{Idealizmus II: idealista tulajdonságmonizmus}

Az idealista tulajdonságmonizmus az a tézis, hogy (az aktuális világban) minden létező mentális természetü. A monizmus e fajtája nyilvánvalóan idealizmus: ha minden létező mentális, akkor a valóság legalapvetőbb szintjét alkotó entitások is mentális természetüek - akármik is ezek az entitások. Valójában az idealista tulajdonságmonizmust kell tekintenünk az „idealizmus” kifejezés egyik fö jelentésének. Attól a filozófustól, aki szerint minden mentális, nehezen tagadhatná meg bárki is az „idealista” jelzőt.

Vegyük észre, hogy az az állítás, miszerint minden létező mentális természetű, kétféleképpen értelmezhető. A példányfizikalizmus-típusfizikalizmus megkülönböztetés mintájára megkülönböztethetünk - nevezzük most így - „példányidealizmust” és „tí-

15 Valamiféle materialista teizmus képviselőire példaként a leggyakrabban a sztoikusokat és Hobbes-ot szokták felhozni, azonban e gondolkodók aligha tekinthetők a klasszikus teizmus képviselőinek is egyben.

16 Természetes módon ugyan, de logikailag nem: az „antirealista teizmus” sem inkonzisztens fogalom. Itt elég megint csak a berkeley-ánus idealizmusra utalnunk, amely - bár lehet, hogy az antirealizmusnak nem a legerősebb formája - realistának semmiképp sem nevezhető. 
pusidealizmust" is. A példányidealizmus mindenképpen implikálja azt az állítást, hogy (az aktuális világban) minden partikuláré mentális partikuláré, azaz instanciál legalább egy mentális tulajdonságot. Ez önmagában azonban még kevés ahhoz, hogy idealizmusról beszéljünk: abban a világban például, amelyben a partikulárék kizárólag nem-mentális fizikai tulajdonságokra ráépülő mentális tulajdonságokat instanciálnak, a mentális nem tekinthető igazán alapvetőnek. Tehát példányidealizmus az a tézis lesz, mely szerint (az aktuális világban) minden partikuláré instanciál legalább egy önálló, azaz nem nem-mentális tulajdonságokra ráépülő (vagy nem-mentális tulajdonságok megjelenése által okozott) mentális tulajdonságot. A típusidealizmus pedig az az állítás, hogy (az aktuális világban) minden tulajdonság mentális tulajdonság.

E tézisekből azonban még nem következik semmi közelebbi arra nézve, hogy tulajdonképpen mik is léteznek. Az idealista tulajdonságmonizmus ugyanúgy kompatibilis a szubsztanciamonizmussal, mint a pluralizmussal, illetve a mentális létezők listája a legkülönfélébb típusú entitásokat tartalmazhatja: a világtól különböző Istent, a világgal azonos Istent, emberi elméket és azok ideáit, monászokat, univerzálékat, mentális tulajdonságokat instanciáló elemi részecskéket stb. Így azt is nehéz megmondani, hogy - a tulajdonságmonizmust általában tagadó metafizikákon kívül - mi számít az elmélet nyilvánvaló tagadásának. Sokan hajlamosak például a fizikalizmust az idealista tulajdonságmonizmus par excellence tagadásának tekinteni, ez azonban nem teljesen egyértelmű. Abból, hogy minden partikuláré instanciál legalább egy, a fenti értelemben önálló mentális tulajdonságot, nem következik, hogy nem igaz, hogy minden partikuláré instanciál (legalább egy) fizikai tulajdonságot is, azaz hogy nem sorolható a „fizikai” kategória alá is egyben. Tehát a példányidealizmus a példányfizikalista tézissel kompatibilisnek tünik.

Továbbá, a minden tulajdonság mentális tulajdonság és a minden tulajdonság fizikai tulajdonság állításokat - azaz a típusidealizmust és a típusfizikalizmust - is csak akkor kell feltétlenül inkonzisztensnek tekintenünk, ha azt gondoljuk, hogy nem lehet minden (instanciált) fizikai tulajdonság azonos valamilyen (instanciált) mentális tulajdonsággal. ${ }^{17}$ Ez utóbbi állítás azonban egyáltalán nem triviálisan igaz. (Legalábbis ha nem tekintjük triviálisan hamisnak a típusazonosság-elméletet: ha nem tekintjük triviálisan hamisnak, hogy bizonyos fizikai tulajdonságok azonosak mentális tulajdonságokkal, akkor az sem tủnik triviálisan hamisnak, hogy minden fizikai tulajdonság azonos valamilyen mentális tulajdonsággal.)

Valójában csak két olyan formája van a fizikalizmusnak, mely első pillantásra is egyértelműen kizárja az idealizmus minden formáját. Az egyik a mentális entitások lé-

17 Amennyiben mindkét állítás igaz, akkor igaz lesz ugyan, hogy a mentális redukálható a fizikaira, de az is igaz lesz, hogy a fizikai redukálható a mentálisra. Tehát a világban a mentális épp úgy alapvető lesz, mint a fizikai. 
tezését tagadó mentális antirealizmus (eliminativizmus): ha mentális nem létezik, akkor nyilván alapvető szerepe sem lehet a világ struktúrájában. ${ }^{18} \mathrm{~A}$ másik a fizikalizmusnak a fizikaiság úgynevezett via negativa koncepcióját elfogadó változata. A via negativa koncepció különböző változataiban az a közös, hogy a „fizikai” fogalom lényegi elemének tekintik, hogy ha egy entitás (például egy tulajdonság) fizikai, akkor alapvetően nem mentális. ${ }^{19}$ Ez konkrétabban annyit jelent, hogy a szóban forgó entitás vagy nem mentális, vagy ha mentális, akkor ontológiailag alapvetőbb nem-mentális entitásokra épül rá. A fizikalizmusnak ez a formája valóban eo ipso tagadja az idealizmust.

Az idealizmus tulajdonságmonista fajtája elvileg éppúgy lehet realista, mint antirealista. Csak annyit állít, hogy minden létező - akár függ ontológiailag a megismerő emberi elmé(k)től, akár nem - mentális természetü. Nem tudom azonban, hogy akad-e olyan realista metafizika, mely egyértelműen azt állítja, hogy szó szerint tényleg minden partikuláré (például egy homokkupac is) vagy szó szerint tényleg minden tulajdonság (például a homokkupacnak lenni tulajdonság is) szellemi természetü. A ténylegesen létező realista változatok közös állítása inkább az a szigorú értelemben vett idealista tulajdonságmonizmusnál gyengébb tézis, hogy a „mentális” predikátum jóval kiterjedtebb részére igaz a világnak, mint azt ma rendesen gondolni szoktuk, sőt világunkban az elme/tudatosság egyáltalán nem ritka, hanem mindenütt - a valóság ontológiailag alapvető szintjén is - jelenvaló. Leginkább e realista változatokat (melyek klasszikus példájaként talán Leibniz metafizikája jut először eszünkbe) szokás „pánpszichizmusnak” nevezni. Ezen elképzelések részletesebb tárgyalására később visszatérünk.

\subsubsection{Idealizmus III: antirealizmus}

Az „idealizmus” kifejezés másik fö jelentésében az antirealizmus különböző változatait jelöli. Első közelítésben tehát azt mondhatjuk, hogy az ebben az értelemben vett idealista elképzelések szerint az elmefüggetlennek tűnő világ valójában - az adott elmélettől függően valamilyen tekintetben és valamilyen mértékben - ontológiailag függ a megismerő emberi elmétől. Így például a konceptuális idealista szerint a fogalmi hálónk - vagy

18 A mentális entitások két nagy típusát szokás megkülönböztetni: a propozicionális attitűdöket és a fenomenálisan tudatos mentális állapotokat. Ezek tárgyalására később még visszatérek, most csak a következőket érdemes megjegyezni. A mentális antirealizmus standard változatai a propozicionális attitüdök létezését tagadják (például Churchland 1981). Ez az álláspont még lehet éppen konzisztens az idealizmussal - az idealizmus azon változataival, mely szerint az alapvető mentális entitások nem propozicionális attitűdök (vagy azokkal rendelkező létezők). A fenomenális tudatosság létezését tagadó álláspontok (például Dennett 1991) azonban nyilván nem. (Bár kérdéses, hogy ez utóbbi elképzelések valóban a fenomenális tudatosság és nem csak valamilyen speciálisan értelmezett „fenomenális tudatosság” tagadásainak tekinthetők.) A mentális antirealizmusról: Márton 2015.

19 Ilyen például Wilson 2006. E koncepcióról lásd még Márton 2019. 
legalábbis annak valamekkora része - nem leképezi a világ elmefüggetlen tagoltságát, hanem bizonyos kategóriákat mi „húzunk rá” a világra; vagy a perceptuális idealista szerint az az érzéki tapasztalatunkban megjelenő kép, mely szerint az észlelt tárgyak az azokat észlelő elmé(k)től függetlenül léteznek, illúzió. (Vegyük észre, az idealista nem a tárgyak létezését, hanem elmefüggetlen voltukat tagadja - hacsak nem tekinti a „fizikai tárgy" fogalom esszenciális elemének az elmefüggetlenséget.) Tehát az idealizmus e fajtájának lényegi állítása nem pusztán annyi, hogy az emberi megismerés tárgyát képező világnak valamilyen szellemi/mentális alapja van, hanem az, hogy ez a mentális alap nem más, mint maga a megismerő elme (nem például valamilyen attól különböző és függetlenül létezo” „tudatosságdarabkák” vagy Isten).

Nem árt hangsúlyozni, hogy az antirealista idealizmus különbözik a szkepticizmustól. Azok az állítások, hogy nem tudhatjuk, hogy a világnak van-e bármilyen elmefüggetlen tagoltsága, (illetve hogy ha van is, nem tudhatjuk, hogy a fogalmi hálónk ahhoz helyesen illeszkedik-e, és nem félretagolja a világot), vagy hogy nem tudhatjuk, hogy vannak-e elmefüggetlenül létező tárgyak, a szkepticizmus különböző formái. Tehát episztemológiai tézisek. „Idealizmusnak” azok az álláspontok nevezhetők, melyek szerint a világnak nincs elmefüggetlen tagoltsága, vagy hogy nincsenek elmefüggetlen fizikai tárgyak. Ezek metafizikai tézisek. ${ }^{20}$ Valójában az antirealista idealizmus egyik - de nem az egyetlen - fö motivációja éppen a szkepticizmus elkerülése. Durván a következő megfontolás alapján: az elmefüggetlen régió számunkra hozzáférhetetlen, ennélfogva megismerhetetlen. Helyezzük hát át a tudásunk tárgyát képező állítások igazságalkotóit a számunkra hozzáférhető saját mentális szféránkba, így hozzáférhetővé, vagyis megismerhetővé válnak. ${ }^{21}$ Teljesen egyértelműen felfedezhető ez a gondolat például Berkeley „immaterializmusa”, Kant „transzcendentális idealizmusa” vagy újabban Putnam „belso realizmusa” mögött ${ }^{22}$ - attól függetlenül, hogy ezek persze számtalan tekintetben egymástól nagyon különböző álláspontok.

Értelemszerűen erről az idealizmusról is elmondhatjuk mindazt, amit fentebb az antirealizmusról mondtunk. Fokozatai vannak, és nehéz pontosan megmondani, hogy milyen mértékủ antirealizmus nevezhető már „idealizmusnak”. A másodlagos tulajdonságok elmefüggetlen voltának tagadása önmagában még nem igazán, viszont az az elképzelés, hogy az elsődleges tulajdonságok a térrel és az idővel együtt is a mi konstrukcióink már minden bizonnyal annak tekinthető. Annyi mindenesetre biztos, hogy az antirealista elképzelések elvileg alapvetően két formát ölthetnek: vagy elismerik valamilyen elmefüggetlen noumenon avagy magánvaló dolog létezését, amibe „beleolvassuk” a megismerésünk tárgyát, vagy teljes mértékben az emberi elme produktumának tekintik

20 Ez akkor is így van, ha bizonyos szerzőknél e megkülönböztetés egyáltalán nem jelenik meg világos formában.

21 Az „igazságalkotó” fogalmáról bővebben: Kocsis 2016.

22 Putnam 1981. 
a világot. Az első változatot Kant, a másodikat Berkeley nevével szokás fémjelezni (annak ellenére, hogy - mint fentebb megjegyeztük - ez Berkeley idealizmusára nem teljesen igaz). Mindkét változat számos formát ölthet, azonban egy-egy említésre méltó szempont szerint mindkettő további két jól elkülöníthető alváltozatra bontható.

Ami az első változatot illeti, arról, hogy mi határozza meg, hogy milyen struktúrát „húzunk rá” az elmefüggetlen alapra, alapvetően kétféleképp vélekedhetünk. Mondhatjuk, hogy ez születésünktől fogva adott, univerzális, minden ember eleve „úgy van bedrótozva", hogy egy bizonyos módon lássa, kategorizálja stb. a világot. Ez például Kant álláspontja. De azt is mondhatjuk, hogy születésünk után tanuljuk meg valahogyan strukturálni a valóságot; hogy hogyan, azt a környezetünk bizonyos elemei határozzák meg. Leginkább ez utóbbi elképzeléseket szokás a gyakran valamilyen jelzővel (mint például „kulturális”, „nyelvi” stb. - részben attól függően, hogy az adott elmélet a környezet mely elemének tulajdonít kiemelt jelentőséget) ellátott „relativizmus” címkével illetni.

A világot teljesen a megismerő elme produktumának tekintő álláspontok pedig aszerint sorolhatók két csoportba, hogy pontosan mit értenek „megismerő elmén”. Az első csoportba sorolható metafizikák szerint a világ ontológiai alapja az egyéni szubjektum. Talán ennek az álláspontnak a monista változatát - amely szerint csak egy egyéni szubjektum létezik - szokás a legtöbbször a „szolipszizmus” kifejezés alatt érteni. E változatot - tudtommal - nem képviseli senki. (Ez azonban nem jelenti azt, hogy nem kell komoly ismeretelméleti problémának tartanunk azt a kérdést, hogy hogyan igazolható, hogy a szolipszizmus hamis.) A pluralista változatok elismerik az egymástól elkülönült egyéni (emberi) elmék létezését, és ezeket tekintik alapvető entitásoknak (a legismertebb ilyen változat a berkeley-ánus idealizmus - most megint csak eltekintve attól, hogy nála Isten az egyéni elméknél is alapvetőbb).

A második csoportba tartozó elképzelések azonban nem csak az elmefüggetlennek tűnő világ elmefüggetlen voltát, hanem az egyéni elmék egymástól elkülönült voltát is illúziónak tekintik. Ezen elképzelések szerint az egyéni szubjektumok csak annyiban tekinthetők a világ ontológiai alapjának, amennyiben megnyilvánulásai/módosulásai ugyanannak az „abszolút elmének”, amelynek minden más elmefüggetlennek tűnő entitás is a produktuma/manifesztációja. Az idealizmus ez utóbbi - szubsztanciamonista - változatát szokás „abszolút idealizmusnak” nevezni. (A nyugati gondolkodásban elsősorban a Kant utáni német idealizmus és a brit idealizmus képviselőinek jó része sorolható ide.)

Az antirealista idealizmus triviálisan inkonzisztens a realizmussal. Ugyanakkor meglehetősen sokféle elképzeléssel lehet konzisztens. Először is azt érdemes észrevennünk, hogy - elvben legalábbis - nem implikálja az idealizmus előző változatát (illetve a tulajdonságmonizmus semmilyen változatát sem): a nem fizikai természetü elmék teremtették 
és tartják létben a (nem mentális) fizikai létezőket állítás például semmivel sem tűnik inkább önellentmondónak, mint a nem fizikai természetü Isten teremtette és tartja létben a (nem mentális) fizikai létezőket állítás. Másodszor pedig azt, hogy a fizikalizmus nem feltétlenül tagadása ennek a fajta idealizmusnak sem: a minden létezö fizikai természetü állítást sem kell feltétlenül inkonzisztensnek tartanunk például a minden létezö az elme manifesztációja állítással - amennyiben nem zárjuk ki eleve, hogy a szóban forgó elme lehet fizikai természetű. Ez azonban nem tűnik a priori kizárhatónak. Például amennyiben igaz az a fentebbi megállapításunk, hogy logikailag lehetséges, hogy egy fizikai elmélet valamilyen, a klasszikus teizmus Istenéhez hasonló entitást tartalmazzon, akkor logikailag az is lehetségesnek tünik, hogy egy fizikai elmélet valamilyen olyan entitást tartalmazzon, amely nagyon hasonlít mondjuk az abszolút idealista abszolút elméjéhez. Itt a kulcskérdés megint csak az, hogy hogyan definiáljuk a „fizikai” predikátumot.

Sarkítva azt mondhatjuk, hogy ennek a fajta idealizmusnak - ellentétben az idealizmus előző változatával - a lényegi állítása nem az, hogy minden entitás szellemi természetű, hanem az, hogy a létezők - legyenek bármilyen természetűek is - a megismerő elme teremtményei.

\section{Kortárs pánpszichizmus}

Az idealizmus gyakorlatilag minden említett formájának akadnak napjainkban is képviselöi. Azért tartom mégis az akadémiai körökben mostanában egyre inkább teret nyerő pánpszichista idealizmust a leginkább figyelemre méltó kortárs idealista tendenciának, ${ }^{23}$ mert az idealizmus e formájának bizonyos változatai viszonylag könnyen beilleszthetőnek tủnnek a ma egyértelműen uralkodónak tekinthető naturalista világképbe. Ezen azt értem, hogy ezen elképzelések képviselői egyfelől elfogadhatják a világ természettudományos leírását a világ (nagyjából) igaz leírásának - azaz lehetnek tudományos realisták -, másfelől pedig nem kell feltételezniük olyan entitások létezését, melyek radikálisan kilógnak e leírásból. Sőt mi több: vannak, akik szerint a pánpszichizmus elfogadása az egyetlen módja annak, hogy el tudjuk kerülni ilyen entitások létezésének feltételezését.

23 Természetesen a pánpszichizmus nem új fejlemény, a nyugati gondolkodásban is több ezer éves történetre tekinthet vissza (erről bővebben: Skrbina 2017). Amikor a pánpszichizmus akadémiai körökben történő mai térnyerésről beszélek, elsősorban nem arra gondolok, hogy e körökben nő a kifejezetten valamilyen pánpszichista álláspontot védelmezők száma, hanem arra, hogy - úgy tűnik - egyre kevesebben tartják eleve abszurd, megfontolásra sem érdemes lehetőségnek azt, hogy a pánpszichizmus akár igaz is lehet. 
Emellett azt is elmondhatjuk, hogy a pánpszichizmus beilleszthetőnek tünik a fizikalista világképbe: de - mint fentebb láttuk - csak akkor, ha „fizikalizmuson” nem mentális antirealista vagy a via negativa koncepción alapuló fizikalizmust értünk. (Többek között ebből is látszik, hogy a fizikalizmus és a naturalizmus nem minden további nélkül azonosítható álláspontok.) Az egyszerủbb fogalmazás kedvéért a továbbiakban általában feltételezni fogom a mentális realizmust, és hogy a „fizikai” terminus definíciójának nem eleme, hogy ha egy entitás fizikai, akkor (alapvetően) nem mentális.

Az alábbiakban először felvázolom a pánpszichizmus néhány fontosabb állítását, majd áttekintem a mellette szóló szerintem ma két legfontosabb érvelési irányt.

\subsection{Mit állít a pánpszichizmus?}

Sajnos - bár nem túl meglepő módon - a pánpszichizmus sem pontosan körülhatárolt fogalom. Ahogy fentebb már utaltunk rá, a legkézenfekvőbb a pánpszichizmust a (realista) idealista tulajdonságmonizmus „puhább” változatának tekinteni, amit durván úgy fogalmazhatunk meg, hogy bár szigorú értelemben nem igaz minden entitásra, hogy mentális, azonban az elme/tudatosság világunkban mindenütt elterjedt, és már az ontológiailag alapvető szinten is jelenlévő jelenség. Minthogy ma a naturalista/fizikalista világkép szerint az ontológiailag legalapvetőbbnek tekinthető entitások minden valószínűség szerint mikrofizikai entitások (elemi részecskék vagy húrok), a pánpszichizmus naturalista (vagy legalábbis a naturalizmushoz közelálló) változatait tekintve ez minimálisan annyit jelent, hogy az alapvető mikrofizikai entitások legalább egy része mentális természetű, és hogy a nem alapvető entitások nagy része legalább abban az értelemben mentális, hogy alkotóelemeik (közt találhatók) ilyen alapvető mentális entitások. ${ }^{24}$

E megfogalmazás persze megint csak igen messze van attól, hogy egzakt definíció legyen. Például nem derül ki belőle pontosan, hogy egy elmélet szerint az alapvető és a nem alapvető entitások mekkora részének kell mentális természetűnek lennie ahhoz, hogy a szóban forgó elmélet már pánpszichistának legyen tekinthető. Azonban minthogy a definiálandó fogalom sem túl egzakt, ez talán megint csak nem kell, hogy túl nagy problémát jelentsen. Az egyszerűség kedvéért mindenesetre a továbbiakban vegyük alapul a pánpszichizmusnak azt a lehetséges változatát, mely szerint minden alapvető entitás mentális természetű.

A következő kérdés, hogy mit jelent az, hogy az alapvető fizikai entitások mentális természetűek. E kérdés megválaszolásához induljunk ki abból a - nem túl merész -

24 Meg kell azonban jegyeznünk, hogy vannak a pánpszichizmusnak olyan változatai is, melyek ontológiailag legalapvetőbb mentális entitásnak az egész univerzum (és nem a legparányibb részeinek) tudatosságát tekintik. Például: Nagasawa - Wager 2016. 
feltételezésből, hogy egy entitás akkor és csak akkor mentális, ha instanciál valamilyen mentális tulajdonságot. Valamely instanciált mentális tulajdonságot pedig nevezzünk most „mentális állapotnak”. ${ }^{25}$ Ezek szerint egy entitás akkor és csak akkor mentális természetű, ha rendelkezik legalább egy mentális állapottal. ${ }^{26} \mathrm{~A}$ kérdés tehát az, hogy mit értsünk azon, hogy az alapvető fizikai entitások rendelkeznek mentális állapotokkal.

Az analitikus filozófiában standard elképzelés szerint a mentális állapotok két nagy típusát különböztethetjük meg: propozicionális attitüdöket és fenomenálisan tudatos mentális állapotokat (kválékat). A propozicionális attitűdök azok a pszichológiai állapotok, melyek tartalma/tárgya egy propozíció, azaz - durván - egy olyan entitás, amely igaz vagy hamis lehet (bármilyen ontológiai kategóriába tartozzon is ez az igazságérték-hordozó entitás). Propozicionális attitűdök például a hitek és a vágyak. Valaki hiheti, hogy most esik az eső, vagy vágyhat arra, hogy most essen az eső. Ebben az esetben hitének/vágyának az a propozíció a tartalma/tárgya, hogy most esik az eső. A propozícionális attitűdök legfontosabb tulajdonsága (a standard elképzelés szerint) az intencionalitás. Az, hogy a propozicionális attitűdök intencionálisak, azt jelenti, hogy reprezentálnak valamit vagy irányulnak valamire. Az a hitem, hogy most esik az eső, arra az eseményre/tényre irányul, azt az eseményt/tényt reprezentálja, hogy most esik az eső. A fenomenálisan tudatos mentális állapotok azok az állapotok, melyekre igaz, hogy van olyan valami, mint az adott állapotban lenni. A testi érzeteink például ilyen mentális állapotok: van olyan valami, mint mondjuk (egy bizonyos típusú) fájdalmat érezni az adott típusú fájdalmat átélő lény számára. ${ }^{27}$

Mindezekkel kapcsolatban persze felmerül egy csomó, a kortárs elmefilozófiában sokat tárgyalt kérdés. Hogy csak néhányat említsünk: van-e olyan (egy vagy néhány) tulajdonság, amelyet minden mentális állapot és csak a mentális állapotok instanciálnak (és amely/amelyek így a mentális megkülönböztető jegyének vagy jegyeinek tekinthetők)? Vannak-e olyan mentális állapotok, melyek intencionálisak és fenomenálisan tudatosak is egyszerre? Ha igen, ekkor viszont az a kérdés merül fel, hogy mi a viszony az intencionalitás és a fenomenális tudatosság között: ezek egymástól független tulajdonságok, vagy az egyik visszavezethető a másikra? Ha az utóbbi a helyzet, akkor melyik melyikre?

Ahhoz, hogy precíz és kimerítő választ adjunk arra a kérdésre, hogy mit kell azon értenünk, hogy egy entitás mentális természetü, jó néhány ezekhez hasonló kérdést is meg kellene válaszolnunk. E kérdésekben azonban - természetesen - nincsen konszenzus, így az sem meglepő, hogy aligha találhatunk olyan pánpszichista elméletet, amely

25 A mentális állapotok és mentális események közt tehető megkülönböztetés számunkra most lényegtelen.

26 Hogy ne kelljen most állást foglalnunk a partikulárék ontológiai szerkezetét érintő bizonyos kérdésekben, azt a lehetőséget se zárjuk ki, hogy e feltétel úgy is teljesülhet, hogy egy entitás azonos egy mentális állapottal.

27 E fogalmakról bővebben: Ambrus 2008, Forrai 2008. 
kimerítő és konszenzuálisan elfogadott választ ad arra a kérdésre, hogy mit kell azon értenünk, hogy mondjuk egy kvark vagy egy elektron mentális természetü - mint ahogyan aligha találhatunk olyan fizikalista elméletet, amely kimerítő és konszenzuálisan elfogadott választ ad arra a kérdésre, hogy mit jelent az, hogy egy agyállapot mentális természetü.

Ám ahhoz, hogy legalább hozzávetőleges képet kapjunk arról, hogy mit állít a kortárs pánpszichizmus, elegendő a következő két kérdést feltennünk:

1. Rendelkeznek-e az alapvető fizikai entitások propozicionális attitűdökkel?

2. Rendelkeznek-e az alapvető fizikai entitások fenomenálisan tudatos állapotokkal?

Ha egy elmélet szerint az első kérdésre a válasz igen, akkor az elmélet biztosan „pánpszichistának" nevezhető (feltéve persze, hogy a szóban forgó elmélet szerint az alapvető fizikai entitások elegendően nagy része rendelkezik propozicionális attitűddel), mivel bármi is legyen a szükséges feltétele annak, hogy egy entitás mentális entitás legyen, abban feltehetően konszenzus van, hogy a propozicionális attitűdökkel rendelkezés elégséges feltétele. Nagyjából a pánpszichizmus e változatát nevezik „pánkognitivizmusnak”.

Ha egy elmélet szerint a második kérdésre a válasz igen, akkor az elmélet biztosan „pánpszichistának” nevezheto” (feltéve persze, hogy a szóban forgó elmélet szerint az alapvető fizikai entitások elegendően nagy része rendelkezik fenomenálisan tudatos mentális állapottal), mivel bármi is legyen a szükséges feltétele annak, hogy egy entitás mentális entitás legyen, abban feltehetően konszenzus van, hogy a fenomenálisan tudatos mentális állapotokkal rendelkezés elégséges feltétel. A pánpszichizmus e változatát nevezzük most „pánfenomenalizmusnak”. ${ }^{28}$

A fentiek fényében tehát úgy tủnik, hogy egy elmélet akkor és csak akkor pánpszichista, ha pánkognitivista és/vagy pánfenomenalista. Azt hiszem, nyugodtan kijelenthetjük, hogy a pánpszichizmus komolyan vehető kortárs formái nem állítják, hogy kvarkoknak vagy elektronoknak hiteik, vágyaik stb. vagy - mondjuk így - gondolataik lennének, tehát nem pánkognitivisták. Azt viszont állítják, hogy az alapvető fizikai entitások valamiféle fenomenális tulajdonságokkal rendelkeznek, azaz a kortárs pánpszichizmus pánfenomenalizmus.

Első közelítésben ezt valahogy úgy képzelhetjük el, hogy ahogyan a nagyon bonyolult struktúrájú idegrendszerrel rendelkező emberi lényeknek vannak fenomenálisan tudatos mentális állapotaik, úgy a kevésbé komplex entitásoknak (mint például állatoknak) is vannak egyszerűbb tapasztalati élményeik, és - ami a lényeg - ez a sorozat sehol

28 E terminust itt most elsősorban az angol panexperientialism megfelelőjeként használom. Az angol nyelvü szakirodalomban a panexperientialism és a panphenomenalism kifejezés is használatos, de nem mindig pontosan ugyanabban az értelemben. 
nem ér véget: a legalsó szinten a legegyszerűbb fizikai entitásoknak is vannak valamiféle nagyon elemi fenomenális tapasztalataik, mondjuk van olyan valami (nevezhetjük „elektronérzetnek”), mint elektronnak lenni.

\subsection{Hogyan lehet érvelni a pánpszichizmus mellett?}

A pánpszichizmus mellett meglehetősen sok érv létezik, ${ }^{29}$ én most csak a kortárs analitikus filozófia klímájához leginkább illeszkedő érvelési vonalat próbálom meg rekonstruálni.

A pánpszichizmus minden formája triviálisan implikálja a mentális realizmust, azaz azt a tézist, hogy léteznek mentális entitások. Ezt a legtöbben nem is vitatják. A mentális entitások - különösen a fenomenálisan tudatos mentális állapotok - létezésének tagadása csak igen kevesek számára tủnik elfogadható álláspontnak. Persze attól, hogy valaki mentális realista, még nem kell pánpszichistának is lennie, elfogadhatja például a fizikalizmus vagy a test-elme dualizmus valamely standard változatát is. Mindkét elképzelés standard formáin természetesen most azokat a változatokat értem, melyek szerint az alapvető fizikai entitások (és általában a legtöbb nem alapvető entitás is az univerzumban) nem mentális természetü. ${ }^{30}$

A pánpszichizmus melletti érvelésben tehát mindenképpen fontos szerepet kell kapnia annak a gondolatnak, hogy a standard dualizmus nem jó választás. A dualizmus különféle változataival - a kortárs filozófusok többsége szerint - a fö probléma az, hogy nehezen összeegyeztethetőek a következő két állítással: 1. a fizikai világ okságilag/magyarázatilag zárt, azaz minden fizikai eseménynek van önmagában elégséges fizikai oka/ magyarázata (ha van oka/magyarázata egyáltalán); 2. mentális entitások okoznak fizikai eseményeket, azaz az epifenomenalizmus hamis.

Az, hogy a fizikai világ okságilag/magyarázatilag zárt, természetesen nem a priori igazság, viszont induktíve ugyancsak jól megalapozott hipotézis. Az sem igényel különösebb magyarázatot, hogy az epifenomenalizmust miért tartják csak kevesen elfogadhatónak. Ha viszont a fizikai események okai csak fizikai entitások/események lehetnek, és a mentális entitások okoznak fizikai eseményeket, akkor a mentális entitások fizikai entitások. (A gondolatmenet ebben a formában természetesen még bőven finomítást igényelne - például explicitté kellene tenni azt a hallgatólagos premisszát, hogy a mentális entitások által okozott fizikai események nem szisztematikusan túldetermináltak nem mentális, fizikai események által -, de pusztán ahhoz, hogy érzékeltessük a problé-

29 Lásd például Skrbina 2017.

30 Ez természetesen nem jelenti azt, hogy a standard fizikalizmus azonos a via negativa koncepcióra épülő fizikalizmussal: abból, hogy azt állítjuk, az alapvető entitások nem mentális természetűek, nem következik, hogy azt is kell állítanunk, hogy az alapvető entitások per definitionem nem mentális természetủek. 
mát, most ebben a formában is megfelelol. ${ }^{31} \mathrm{~A}$ pánpszichista e megfontolás alapján két logikailag lehetséges formában is elutasíthatja a dualizmust.

Az első, hogy elfogadja a fizikalizmust, de nem a standard formájában. A pánpszichista fizikalista álláspontja természetesen az lesz, hogy - többek között - az alapvető entitások fizikai természetű, de egyben mentális természetű entitások is. Egy logikailag lehetséges pánpszichista álláspont például, hogy az elektronnak lenni fizikai tulajdonság azonos az elektronérzet mentális tulajdonsággal. Minthogy ebben az esetben a pánpszichista elmélete implikálni fogja azt az állítást, hogy minden mentális entitás fizikai természetű is egyben, a fizikai világ oksági zártságának elismerésével együtt is tarthatja okságilag hatékonynak a mentális állapotokat.

A pánpszichista második lehetősége, hogy elutasítja a fizikalizmust (mert mondjuk szerinte a „mentális” és a „fizikai” egymást kizáró fogalmak), és egyszerüen azt mondja, hogy az alapvető entitások mentális (és nem fizikai) természetűek. Ugyanakkor a naturalizmust (durván: azt a tézist, hogy az aktuális világban csak olyan entitások léteznek, melyek szerepelnek a természettudományos elméleteink ontológiájában) nem utasítja el a fizikalizmussal együtt. Az alapvető entitásokat tehát ugyan nem fizikai, de természeti entitásoknak fogja tartani, és ezzel együtt a fizikai világ oksági/magyarázati zártságának tézisét egyszerủen kicseréli a természeti világ oksági/magyarázati zártságának tézisére, amit első nekifutásra mondjuk a következőképp fogalmazhatunk meg: minden a természettudományos elméleteink fogalmi készletével leírható eseménynek van önmagában elégséges, a természettudományos elméleteink fogalmi készletével maradéktalanul leírható oka/magyarázata. Azáltal, hogy az alapvető természeti entitásokat mentális entitásoknak tekinti, e tézissel - ami empirikusan semmivel nem inkább vagy kevésbé megalapozott, mint az előző változat - semmiképp nem kerül ellentmondásba.

Bármelyik lehetőséget választja is azonban (a kettő közötti különbség inkább csak verbális különbségnek tủnik), azt még mindenképpen meg kell indokolnia, hogy miért tartja elfogadhatatlannak a dualizmussal együtt a fizikalizmus standard változatait is. Az alábbiakban röviden felvázolom a - megítélésem szerint - két legfontosabb ilyen irányú pánpszichista érvelés alapgondolatait. ${ }^{32}$

31 Ez a fajta antidualista érvelés minden bizonnyal David Lewis 1966-os cikkében jelenik meg először világos formában, lásd Lewis 1966.

32 Általában a standard materialista megközelítés egy nagy hatású kritikája: Nagel 2012. 


\subsubsection{A magyarázati szakadékra épülő érvek ${ }^{33}$}

Ma valószínűleg a legtöbb filozófus - akár fizikalista, akár nem - egyetért azzal a megállapítással, hogy a fizikalizmus számára a legnagyobb kihívást a fenomenális tulajdonságok létezésének ténye jelenti. Konkrétabban arról van szó, hogy - sokak szerint - úgy tűnik, hogy a fizikalista elméletek nem képesek megmagyarázni, hogy a nem mentális/ fenomenális fizikai entitások ilyen-olyan kombinálódása/konfigurációja hogyan eredményezheti fenomenális tapasztalatok megjelenését a világban. E problémát szokás úgy megfogalmazni, hogy a fenomenális és a fizikai közt „magyarázati szakadék” húzódik.

Az, hogy a fizikalista elméletek nem képesek megmagyarázni a fenomenális tapasztalatok létezését, gyakorlatilag azt jelenti, hogy a fizikalista állítása szerint fenomenális élményekkel azonos (és/vagy fenomenális élmények megjelenését szükségszerűsitő) fizikai állapotok létezéséből nem tudunk deduktíve fenomenális élmények létezésére következtetni. ${ }^{34}$ Nevezzük például a fájdalommal korreláló fizikai állapotot - ahogy szokás - „C-rostok tüzelésének”. A típusazonosság-elmélet képviselője szerint például a fájdalom azonos a C-rostok tüzelésével. ${ }^{35}$ Azonban el tudjuk gondolni, hogy egy lénynek tüzelnek a C-rostjai, és nem érez fájdalmat. Úgy is fogalmazhatunk, hogy nem tudjuk a priori, hogy ha egy lénynek tüzelnek a C-rostjai, akkor a lény fájdalmat érez. De akárhogy is fogalmazunk, a lényeg: nem értjük, hogy a C-rostok tüzeléséből hogyan lesz olyan valami, mint fájdalmat átélni.

Továbbá úgy tűnik, hogy az, hogy ezt nem értjük, nem a fizikai világra vonatkozó ismereteink jelenleg hiányos voltából fakad. Bármilyen új ismeretekre fogunk is a jövőben szert tenni a nem mentális/fenomenális fizikai entitások természetéről, konfigurációinak különböző módjairól stb., amennyire ma meg tudjuk ítélni, ezen új ismeretek semmit nem fognak segíteni annak megértésében, hogy a nem fenomenálisból hogyan lesz fenomenális.

Bizonyos dualista érvelések ezen a vonalon tovább haladva a következőt próbálják megmutatni: a magyarázati szakadék létezése végső soron azt a belátást kell, hogy eredményezze, hogy kizárólag csak fizikai entitások konfigurációja nem is lehet elégséges feltétele fenomenális entitások megjelenésének. Ezek az érvek tehát egy episztemológiai

33 Az ilyen típusú érveket - mondjuk így - ,az emergencia lehetetlenségéből vett érveknek” (Anti-Emergence vagy Non-Emergence Argument) szokták címkézni. Minthogy az „emergencia” különösen homályos, különböző szerzők által eltérő értelemben használt fogalom, én itt szándékosan kerülöm a használatát. A két legtöbbet hivatkozott ilyen típusú érvelés: Nagel 1979, Strawson 2006. Az „emergencia” fogalmáról lásd például Chalmers 2003.

34 A mai napig a legvilágosabb kifejtése e problémának: Levine 2008.

35 Bár ez így nem éppen szabatos megfogalmazása annak, amit a típusazonosság-elmélet állít (erről bővebben: Tőzzér 2008), most nem szükséges tovább pontosítanunk. 
tézistől egy metafizikai konklúzióhoz jutnak el. Például a tulajdonságdualizmus ${ }^{36}$ standard változatainak alaptézise, hogy a fenomenális tapasztalatok úgy jelennek meg, hogy a komplexitás egy bizonyos szintjét elérő nem fenomenális fizikai struktúrák valamiért elkezdenek a fizikai tulajdonságoktól radikálisan különböző, a fizikai tulajdonságokhoz képest „új”, nem fizikai fenomenális tulajdonságokat instanciálni. E metafizikai tézis természetesen egyfajta megoldást kínál a magyarázati szakadék problémára is. Ha feltesszük, hogy igaz, többé már nem kell azon a kérdésen törni a fejünket, hogy hogyan lesz a fizikaiból fenomenális: mivel belátjuk, hogy nem lesz. (Ugyanakkor ebben az esetben a dualistának meg arra a kérdésre kell választ adnia, hogy a komplex fizikai struktúrák miért kezdenek el nem fizikai tulajdonságokat instanciálni.)

Mind a fizikalizmus, mind a tulajdonságdualizmus standard formáinak képviselői abban tehát egyetértenek, hogy a fenomenális tudatosság megjelenése (legalábbis az aktuális világban) komplex fizikai rendszerek létezéséhez kötött. Kevésbé komplex pláne alapvető - entitások nem rendelkezhetnek fenomenális (és általában mentális) tulajdonságokkal. A dualista szerint azonban - természetesen ebben tér el álláspontja a fizikalistától - a nem mentális/fenomenális alapvető fizikai alkotóelemek komplex elrendeződése nem eredményezheti fenomenális tulajdonságok megjelenését.

A magyarázati szakadék problémájára épülő pánpszichista érvelés nagy vonalakban a következőképpen foglalható össze. A pánpszichista abban egyetért a dualistával, hogy a nem mentális/fenomenális alapvető fizikai alkotóelemek komplex elrendeződése nem eredményezheti, de legalábbis nem magyarázza meg fenomenális tulajdonságok megjelenését. Ezen az alapon utasítja el a standard fizikalizmust - hasonlóan a dualistához. Ugyanakkor a pánpszichista a dualizmust is elutasítja (például a mentális okozással kapcsolatos problémák miatt). Mármost ha a nem mentális/fenomenális alapvető fizikai alkotóelemek komplex elrendeződése nem eredményezheti, de legalábbis nem magyarázza meg fenomenális tulajdonságok megjelenését, továbbá ha e tulajdonságok nem is a fizikai entitásoktól radikálisan különböző, azokhoz képest új, nem fizikai entitások, akkor csak egy dolgot mondhatunk - hangzik a pánpszichista konklúzió: az alapvető fizikai entitások már maguk is fenomenálisak. A fenomenalitás nem az alsóbb szintekhez képesti újdonságként megjelenik valahol a komplexitás egy bizonyos szintjén, hanem „kezdettől fogva” jelen van a fizikai világ legalapvetőbb szintjén is. Ha ez utóbbi állítás igaz, akkor a magyarázati szakadék probléma természetesen eltủnik, hiszen nem kell megmagyaráznunk a megmagyarázhatatlant, azt, hogy hogyan lesz a nem fenomenálisból fenomenális: minthogy minden fenomenális.

Ennek a fajta pánpszichista érvelésnek természetesen legalább három sarkalatos pontja van, melyeket három kérdés formájában is megfogalmazhatunk. Az első: a ma-

36 A példányfizikalizmus azon változata, mely szerint fizikai partikulárék fizikai tulajdonságaik mellett instanciálhatnak nem a fizikai tulajdonságokra ráépülő mentális tulajdonságokat. 
gyarázati szakadék valóban kezelhetetlen problémát jelent a standard fizikalizmus számára? A második: a dualizmus valóban (minden formájában) tarthatatlan álláspont? A harmadik: a pánpszichizmus valóban megmagyarázza a fenomenális tulajdonságok létezését? Jórészt az első két kérdés körül forogtak az utóbbi évtizedekben az elme természetét érintő viták az analitikus elmefilozófiában, e kérdések tárgyalására most nem térek ki. ${ }^{37}$ Azt azonban mindenképpen meg kell említenünk, hogy a harmadik kérdésre egyáltalán nem egyértelmủen ,igen” a válasz.

A fentebb vázolt pánpszichista elképzelés ugyanis az lenne, hogy az alapvető (fizikai) entitásoknak megvan a saját elemi fenomenális tudatosságuk, és valahogy ezek a „tudatosságdarabkák" konstituálják az általunk ismert magasabb szintű fenomenális tulajdonságokat/állapotokat, mint például az emberi fájdalmat, vagy akár individuális tudatokat. Felmerül azonban a kérdés: mennyivel értjük kevésbé azt, hogy a nem mentális/ fenomenális fizikai entitások ilyen-olyan kombinálódása/konfigurációja hogyan eredményezheti e tapasztalatok megjelenését, mint azt, hogy a saját elemi tudatossággal rendelkező alapvető entitások ilyen-olyan kombinálódása/konfigurációja hogyan eredményezheti az általunk ismert fenomenális tapasztalatok megjelenését?

Úgy tűnik, a pánpszichista magyarázata semmivel nem jobb, mint a standard fizikalistáé - és ez természetesen az egész érvet aláássa. Sőt, a pánpszichista talán még egy fokkal rosszabb helyzetben is van a fizikalistánál. Ugyanis, bár azt (ma legalábbis) valóban nem értjük, hogy alapvető fizikai entitások kombinálódása hogyan eredményezheti a fenomenalitás megjelenését, de azt legalább értjük valamennyire, hogy mit jelent, hogy alapvető fizikai entitások kombinálódnak. Ezzel szemben erősen kérdéses, hogy bármennyire is érthetö-e, hogy mit jelent az, hogy különálló fenomenális tudatosságdarabkák kombinálódnak, kiadva valamilyen egységes tudatosságot.

Ez az úgynevezett „,kombinációs probléma” (combination problem), ${ }^{38}$ amire ez idáig nem született kielégítő pánpszichista válasz. És - valljuk meg - nem is igen várható, hogy a jövőben születik: semmivel nem tűnik inkább valószínűnek az, hogy a jövőbeli pánpszichista elméletek érthetővé teszik, hogy a saját elemi tudatossággal rendelkező alapvető entitások kombinálódásából hogyan alakulnak ki az általunk ismert fenomenális élmények, mint az, hogy a jövőbeli fizikalista/fizikai elméletek érthetővé teszik, hogy a nem fenomenális fizikai entitások kombinálódásából hogyan alakulnak ki ilyen élmények.

Természetesen a pánpszichista megteheti azt, hogy a magasabb szintü, általunk is ismert fenomenális entitásokat nem azoknál egyszerủbb fenomenális entitások által konstituált entitásoknak tekinti (tehát a kombinációs probléma a pánpszichizmus nem minden formáját érinti), ebben az esetben azonban a magasabb szintű fenomenális tu-

37 Lásd például: Ambrus et al. 2008, 9-134, 297-408; Tőzsér 2009, 206-54; Pöntör 2015.

38 Seager 2004. 
lajdonságok létezéséből kiindulva nem érvelhet az alapvető (fizikai) entitások fenomenális volta mellett.

\subsubsection{Intrinzikus tulajdonság érv}

A pánpszichizmus melletti másik fó érvelési irány alapgondolatát a legegyszerübben talán valahogy a következő - durván leegyszerüsített - formában foglalhatjuk össze: induljunk ki abból, hogy a materializmus igaz. Ekkor azt mondhatjuk, hogy az anyagi világnak van egy olyan szegmense, amelynek ismerjük a belső természetét, nevezetesen a saját testünk (vagy annak valamely része: agyunk/idegrendszerünk). Továbbá azt is meg kell állapítanunk, hogy az anyagi világnak ez az egyetlen ilyen szegmense. Azon egyszerű oknál fogva, hogy a világ összes entitása közül ez az egyetlen olyan entitás, melyet „belülről” vagyunk képesek megtapasztalni. A tapasztalás e módját nevezzük „introspekciónak” (vagy „reflexiónak”). A világ összes többi részét csak „kívülről” ismerhetjük. Mármost ha feltesszük, hogy a tulajdonságmonizmus igaz (ezt ugye most feltesszük, mivel a materializmus tulajdonságmonizmus), akkor azt kell mondanunk, hogy a világ minden (anyagi) entitása ugyanolyan belső természetủ. Minthogy pedig a világ egyetlen olyan anyagi entitásának, melynek ismerjük a belső természetét, a belső természete mentális (az introspekció tárgyai nyilvánvalóan mentális természetűek), ebből az következik, hogy a világ minden anyagi entitásának a belső természete mentális. Ezt ráadásul még az a tény is megerősíteni látszik, hogy az általunk egyetlen belülről ismert entitástípus (test/agy/idegrendszer) kívülről nézve éppen úgy nem mentális (anyagi) természetűnek látszik, mint a világ általunk belülről nem ismert összes többi része.

Nagyjából ez a gondolat az alapja a pánpszichizmus melletti úgynevezett „intrinzikus tulajdonság” (intrinsic property) vagy „intrinzikus természet” (intrinsic nature) érveknek. ${ }^{39}$ Ezen érvek - a fentinél szofisztikáltabb változataikban - például a következő állításokhoz hasonló állításokra szoktak épülni: a fizika tudománya (és általában a természettudományok) csak a világot alkotó entitások extrinzikus tulajdonságait tárják fel, intrinzikus tulajdonságaikat nem; vagy: a fizika tudománya (és általában a természettudományok) csak a világot alkotó entitások diszpozicionális tulajdonságait tárják fel, kategorikus tulajdonságaikat nem.

Mivel az intrinzikus-extrinzikus, illetve a kategorikus-diszpozicionális felosztások e kérdéstől függetlenül, önmagukban is meglehetősen sok vitát váltanak ki, talán jobb, ha most egyszerủen úgy fogalmazunk, hogy az ide tartozó érvek azon az állításon alapulnak, hogy a fizika és általában a természettudomány a világot alkotó entitások belső -

39 Például Goff 2017, 2019. 
azaz más entitásoktól függetlenül fennálló - tulajdonságairól nem mond semmit, hanem csak ezen entitások egymáshoz való viszonyának, azaz relációs tulajdonságainak leírására szorítkozik. Mondhatjuk úgy is, hogy a természettudomány a világ struktúráját írja le, de arról hallgat, hogy a világ „miből van”.

Ezen elképzelés egy lehetséges változata például, hogy a fizikai elméletekben szereplő tulajdonságok szereptulajdonságok. Az elektronnak lenni tulajdonság például nem más, mint egy szereptulajdonság, amely részben a következőképp írható le: elektron az a bármilyen belsö természetü dolog, amely taszít más elektronokat (azaz bármilyen dolgot, amely betölti ugyanazt a szerepet, mint ő maga), és vonzza a protonokat. Természetesen a protonnak lenni tulajdonság is egy szereptulajdonság lesz, ami részben a következőképp írható le: proton az a bármilyen belsö természetü dolog, amely vonzza az elektronszerepet betöltő entitásokat, és taszítja a protonszerepet betöltő entitásokat. A lényeg, hogy a fizika csak ezen „bármilyen természetű dolgok” egymáshoz való viszonyáról szolgáltat számunkra információkat, de arról nem mond semmit, hogy e dolgok önmagukban milyenek.

Mármost ha elfogadjuk, hogy a természettudomány csak a világot alkotó entitások egymáshoz való viszonyáról tesz állításokat, akkor - úgy tűnik - azt is el kell fogadnunk, hogy a tudomány által a világról nyújtott leírásból kimarad valami fontos. Valamely struktúra ismeretéből ugyanis tényleg nem következik, hogy ismerjük a kérdéses struktúrát felépítő elemek belső természetét is. Például abból, hogy valaki megért egy leírt szöveget, joggal következtethetünk arra, hogy ismeri a jelek (betűk) egymáshoz való viszonyát, de arra nem, hogy tudja, mi a nyomdafesték anyaga. De az is nyilvánvaló, hogy ugyanazt a struktúrát egymástól nagyon különböző belső természetű alkotóelemek is realizálhatják, mint például, amikor ugyanaz a szöveg jelenik meg a monitoron, mint a papíron. Tehát elvileg akár radikálisan különböző természetű világoknak lehet ugyanolyan fizikájuk.

Persze abból, hogy a tudomány nem szolgáltat számunkra semmilyen információt arra nézve, hogy milyen a világot alkotó entitások belső természete, még nem következik, hogy a világot alkotó entitások belső természete mentális. Viszont ez az a pont, ahol úgy érvelhet a pánpszichista, hogy vannak olyan entitások, melyeknek ismerjük a belső természetét: ezek a saját mentális állapotaink, melyek belső természete mentális. Ennek fényében pedig legalábbis észszerủ feltételeznünk, hogy a mentális tulajdonságok a világot alkotó entitások azon belső tulajdonságai, melyek a világ természettudományos leírásából kimaradnak. (De legalábbis a fenomenális tulajdonságok, annyi ugyanis biztos, hogy az introspektív tapasztalatban a mentális állapotaink fenomenálisan tudatos enti- 
tásokként jelennek meg.) A pánpszichizmus e formáját „russelliánus pánpszichizmusként" szokták emlegetni. ${ }^{40}$

A russelliánus pánpszichizmus mellett szól, hogy egyfajta megoldást kínál a test-elme problémára is. Minden bizonnyal nem járunk messze az igazságtól, ha azt mondjuk, hogy e probléma abban a tényben gyökerezik, hogy egyfelől - most az egyszerüség kedvéért fogalmazzunk így - az elme az introspektív tapasztalatban, „belülről” radikálisan különböző természetűnek tủnik, mint saját testünk/agyunk, másfelől viszont az is nyilvánvaló, hogy nagyon szoros kapcsolat van e két radikálisan különbözőnek tűnő entitás között. Az alapvető kérdés mármost a következő: ha valóban különböznek, akkor miért van, és fóleg hogyan lehetséges ilyen szoros kapcsolat közöttük, ha pedig nem különböznek, akkor miért tűnnek ennyire különbözőnek? Russelliánus pánpszichista alapon viszont adja magát a következő válasz: az introspekció során ugyanazon entitások (innen ered a szoros kapcsolat) belső tulajdonságait tapasztaljuk, amely entitások között fennálló, a belső tulajdonságaiktól különböző (innen ered a különbözőség) relációs tulajdonságok konstituálják az érzékszerveinkkel „kívülről” észlelhető, „,fizikainak” nevezett létezőket, mint például az emberi agyat.

E megoldási javaslat első pillantásra valóban ígéretesnek tűnik, azonban kérdés, hogy a kidolgozott formái bármennyivel is problémamentesebbek-e, mint a standard fizikalista vagy dualista elméletek. Az például rögtön szembetűnő vonása ennek az elgondolásnak, hogy a tulajdonságdualizmus egy formájának tűnik (a mentális belső tulajdonságok és a relációs fizikai tulajdonságok dualizmusa), így pedig kérdéses, hogy el tudja-e kerülni a mentális okozás problémáját. ${ }^{41}$

Általában is elmondhatjuk erről az érvelési irányról, hogy első pillantásra meggyőzőnek tünik, a részleteket tekintve azonban már kevésbé. A leggyengébb pontja nyilvánvalóan az, hogy nehezen tünik igazolhatónak az az állítás, hogy a fizikai entitások belső tulajdonságai mentális entitások, pusztán azon az alapon, hogy ezen entitásoknak valamilyen belső tulajdonságokkal kell rendelkezniük. A fizikai világ azon vékony szelete, melyről nagy valószínűséggel tudjuk, hogy mentális, nagyon csekély empirikus bázist jelent egy olyan induktív következtetés levonására, melynek konklúziója az, hogy a fizikai világ minden alkotóeleme mentális. Az is kérdéses, hogy a relációs (fizikai) tulajdonságok létezésére a legjobb (ontológiailag a legtakarékosabb, a világról alkotott egyéb is-

40 Bertrand Russell egyike volt az első olyan gondolkodóknak, akik a fizikát illetően hasonló gondolatokat fogalmaztak meg. E koncepciónak nem csak pánpszichista, hanem standard fizikalista és neutrális monista változata is lehetséges. Lásd Russell 1927, Holman 2008, Chalmers 2013.

41 Howell 2014. 
mereteinkhez a legjobban illeszkedő stb.) magyarázat az, hogy e tulajdonságoknak mentális alapjai vannak. ${ }^{42}$

\subsection{A pánpszichizmus kilátásai}

Azt hiszem, hogy a pánpszichizmus ellen nincsenek igazán nyomós érvek. Az az „ellenérv”, hogy erősen „kontraintuitív” álláspontnak tünik, nemigen mond többet annál, mint hogy hétköznapi meggyőződéseinkkel nem fér össze. Ezen az alapon azonban például a kvantummechanikát is elutasíthatnánk. Továbbá a világról alkotott hétköznapi meggyőződéseink, „intuícióink” rendszere nagyon is változékony. Az az állítás például, hogy a mentális folyamatok azonosak agyi folyamatokkal, minden bizonnyal ma is sokak számára kontraintuitív, háromszáz évvel ezelőtt pedig minden bizonnyal még inkább ez volt a helyzet.

Azt is nehéz elképzelni, hogy valakinek sikerüljön valamilyen, a pánpszichizmust cáfoló - konkluzív - a priori érvvel előállnia. A tapasztalatra hivatkozva pedig legfeljebb csak annyit állíthatunk joggal, hogy az általunk (valamennyire) ismert mentális tulajdonságokhoz „passzoló” viselkedést csak azok a fizikai rendszerek produkálnak, amelyeknek rendesen valamilyen elmét tulajdonítunk. Arról azonban fogalmunk sincs, hogy az általunk nem ismert mentális tulajdonságokhoz milyen viselkedés passzolna. Lehet, hogy pont olyan, amilyet a szerintünk nem mentális fizikai létezők mutatnak.

Így a pánpszichizmus jövőbeli sorsát - ha csak a racionális szempontokat vesszük figyelembe - elsősorban az fogja meghatározni, hogy a pánpszichizmus képviselőinek mennyire meggyőzően sikerül megmutatniuk, hogy az általuk képviselt alternatíva határozottan jobb, mint a standard fizikalista és dualista vetélytársai. A fentiek alapján azonban ez számomra egyelőre nem tủnik túlzottan reményteljes vállalkozásnak.

42 Valójában abban a kérdésben sincs konszenzus, hogy kell-e egyáltalán feltételeznünk bármilyen belső tulajdonság létezését. Vannak, akik szerint nem, például Ellis 2001, McKitrick 2003. És persze ezzel sokan vitatkoznak, például Robinson 1982, Goff 2017. 


\section{Bibliográfia}

Ambrus Gergely - Demeter Tamás - Forrai Gábor - Tözsér János, szerk. 2008. Elmefilozófia: Szöveggyüjtemény. Budapest: L'Harmattan Kiadó.

Ambrus Gergely. 2008. „Tudatosság.” In Elmefilozófia: Szöveggyüjtemény, szerk. Ambrus Gergely - Demeter Tamás - Forrai Gábor - Tőzsér János, 297-318. Budapest: L’Harmattan Kiadó.

Banks, Erik C. 2010. „Neutral monism reconsidered.” Philosophical Psychology 23/2: 173-87.

Brüntrup, Godehard - Ludwig Jaskolla, szerk. 2016. Panpsychism. New York: Oxford University Press.

Chalmers, David. 1996. The Conscious Mind. New York: Oxford University Press.

Chalmers, David. 2003. „Az emergencia változatai.” Ford. Csordás Attila. Világosság 44/3-4: 43-51.

Chalmers, David. 2013. „Panpsychism and Panprotopsychism.” [http://consc.net/papers/panpsychism.pdf] (2021.03.24.)

Chalmers, David. 2019. „Idealism and the Mind-Body Problem.” In The Routledge Handbook to Panpsychism, szerk. William Seager, 353-73. London: Routledge.

Churchland, Paul M. 1981. „Eliminative Materialism and the Propositional Attitudes.” Journal of Philosophy 78/2: 67-90.

Dennett, Daniel C. 1991. Consciousness Explained. London: Penguin.

Ellis, Brian. 2001. Scientific Essentialism. Cambridge: Cambridge University Press.

Forrai Gábor. 2008. „Intencionalitás.” In Elmefilozófia: Szöveggyüjtemény, szerk. Ambrus Gergely - Demeter Tamás - Forrai Gábor - Tózsér János, 137-58. Budapest: L'Harmattan Kiadó.

Foster, John. 1982. The Case for Idealism. London: Routledge \& Kegan Paul.

Foster, John. 2008. A World for Us: The Case for Phenomenalistic Idealism. Oxford, New York: Oxford University Press.

Goff, Philip. 2017. Consciousness and Fundamental Reality. New York: Oxford University Press.

Goff, Philip. 2019. Galileo's Error: Foundations for a New Science of Consciousness. New York: Pantheon Books.

Goff, Philip - William Seager - Sean Allen Hermanson. 2017. „Panpsychism.” The Stanford Encyclopedia of Philosophy, szerk. Edward N. Zalta. [https://plato.stanford.edu/entries/panpsychism/] (2021.03.24.)

Goldschmidt, Tyron - Kenneth L. Pearce, szerk. 2017. Idealism: New Essays in Metaphysics. Oxford: Oxford University Press.

Guyer, Paul - Rolf-Peter Horstmann. 2015. „Idealism.” In The Stanford Encyclopedia of Philosophy, szerk. Edward N. Zalta. [https://plato.stanford.edu/entries/idealism/] (2021.03.24.)

Holman, Emmett. 2008. „Panpsychism, Physicalism, Neutral Monism and the Russellian Theory of Mind." Journal of Consciousness Studies 15/5: 48-67.

Howell, Robert. 2014. „The Russellian Monist's Problems with Mental Causation.” Philosophical Quarterly 65/258: 22-39.

Huoranszki Ferenc. 2001. Modern metafizika. Budapest: Osiris Kiadó. 
James, William. 1981. „Létezik-e »tudat«?” Ford. Márkus György. In Pragmatizmus, szerk. Szabó András Görgy, 301-24. Budapest: Gondolat Kiadó.

Kocsis László. 2016. Az igazságalkotás metafizikája. Budapest: L’Harmattan Kiadó.

Langton, Rae. 1998. Kantian Humility: Our Ignorance of Things in Themselves. Oxford: Clarendon Press.

Levine, Joseph. 2008. „A milyenség kihagyásáról.” Ford. Eszes Boldizsár. In Elmefilozófia: Szöveggyüjtemény, szerk. Ambrus Gergely - Demeter Tamás - Forrai Gábor - Tözsér János, 354-73. Budapest: L'Harmattan Kiadó.

Lewis, David. 1966. „An Argument for the Identity Theory.” The Journal of Philosophy 63: $17-25$.

Mach, Ernst. 1886. Az érzetek elemzése. Ford. Erdős Lajos. Budapest: Franklin.

Márton Miklós. 2015. „Mentális antirealizmus és a megkülönböztető jegy problémája.” In Realizmus, magyarázat, megértés, szerk. Márton Miklós - Molnár János - Tözsér János, 237-51. Budapest: L'Harmattan Kiadó.

Márton Miklós. 2019. „Mi a »fizikai«? Kísérletek a »fizikai« fogalmának meghatározására a kortárs fizikalizmusvitában.” Elpis 12/2: 79-106.

McKitrick, Jennifer. 2003. „A Case for Extrinsic Dispositions.” Australasian Journal of Philosophy 81: 155-74.

Nagasawa, Yujin - Khai Wager. 2016. „Panpsychism and Priority Cosmopsychism.” In Panpsychism, szerk. Brüntrup, Godehard - Ludwig Jaskolla, 113-29. New York: Oxford University Press.

Nagel, Thomas. 1979. „Panpsychism.” In Mortal Questions, 181-95. Cambridge: Cambridge University Press.

Nagel, Thomas. 2012. Mind and Cosmos: Why the Materialist Neo-Darwinian Conception of Nature is Almost Certainly False. Oxford: Oxford University Press.

Newlands, Samuel. 2011a. „Hegel's Idealist Reading of Spinoza.” Philosophy Compass 6/2: 100-108.

Newlands, Samuel. 2011b. „More Recent Idealist Readings of Spinoza.” Philosophy Compass 6/2: 109-19.

Pöntör Jenő. 2015. „Magyarázat és fizikalizmus.” In Realizmus, magyarázat, megértés, szerk. Márton Miklós - Molnár János - Tózsér János, 13-30. Budapest: L'Harmattan Kiadó.

Putnam, Hilary. 1981. Reason, Truth and History. Cambridge: Cambridge University Press.

Quine, Willard Van Orman. 1999. „Naturalizált ismeretelmélet.” Ford. Farkas Katalin. In Tudományfilozófia: szöveggyüjtemény, szerk. Forrai Gábor - Szegedi Péter, 369-82. Budapest: Áron Kiadó.

Robinson, Howard. 1982. Matter and Sense. Cambridge: Cambridge University Press.

Robinson, Howard. 2016. From the Knowledge Argument to Mental Substance: Resurrecting the Mind. Cambridge: Cambridge University Press.

Russell, Bertrand. 1921. The Analyis of Mind. London: Allen and Unwin

Russell, Bertrand. 1927. The Analysis of Matter. London: Allen and Unwin. 
Seager, William. 2004. „Tudat, információ és pánpszichizmus.” Ford. Sutyák Tibor. Vulgo 5/2: 47-62.

Skrbina, David. 2007. „Panpsychism.” In Internet Encyclopedia of Philosophy, szerk. James Fieser - Bradley Dowden. [https://iep.utm.edu/panpsych/] (2021.03.24.)

Skrbina, David. 2017. Panpsychism in the West, Revised Edition. Cambridge, MA: MIT Press.

Sprigge, Timothy. 1983. A Vindication of Absolute Idealism. London: Routledge and Kegan Paul.

Strawson, Galen. 2006. „Realistic Materialism: Why Physicalism Entails Panpsychism.” Journal of Consciousness Studies 13/10-11: 3-31.

Tőzsér János. 2008. „Általános bevezetés: a test-lélek probléma.” In Elmefilozófia: Szöveggyüjtemény, szerk. Ambrus Gergely - Demeter Tamás - Forrai Gábor - Tőzsér János, 9-85. Budapest: L'Harmattan Kiadó.

Tőzsér János. 2009. Metafizika. Budapest: Akadémiai Kiadó.

Wilson, Jessica. 2006. „On Characterizing the Physical.” Philosophical Studies 131/1: 61-99. 